\title{
Variables influencing nitrogen surplus of dairy farms in Flanders
}

\author{
Elena RAMÍREZ*, Dirk REHEUL \\ Department of Plant Production, Faculty of Bioscience Engineering, Ghent University, Coupure Links 653, 9000 Ghent, Belgium
}

(Accepted 11 March 2010)

\begin{abstract}
Nitrogen losses are major concerns for agriculture and policy-makers. Intensification of livestock production has contributed to an increase in nutrient surpluses. Here, we performed an exploratory analysis of the variables influencing the nitrogen surplus in Flemish dairy farms. We used the large dataset of the Farm Accountancy Data Network, holding technical and economic data of Flemish farms. A statistical model is proposed by performing multiple linear regression with several variable selection procedures. This approach focuses on a deep statistical analysis and interpretation of the model. The final model contains the following variables: $\mathrm{N}$ in fertilizers (kg/ha), $\mathrm{N}$ in concentrates $(\mathrm{kg} / \mathrm{ha}), \mathrm{N}$ in by-products $(\mathrm{kg} / \mathrm{ha})$ and $\mathrm{N}$ in straw $(\mathrm{kg} / \mathrm{ha})$, which refer to purchased inputs, livestock units of dairy cows per ha and percentage of arable crops. The input variables show a positive sign, indicating that the higher the nitrogen inputs, the higher the nitrogen surplus. Contrary to current knowledge, a lower nitrogen surplus was observed for farms with a higher number of livestock units of dairy cows per ha, holding the rest of the $\mathrm{N}$ inputs constant. A higher stocking density is compatible with a higher agricultural sustainability. The unexpected negative correlation of livestock units of dairy cows per ha with the dependent variable surplus per ha means that the higher the stocking density - under a certain limit - the lower the surplus of nitrogen will be, provided that feed inputs to the farm and cows are kept at a constant level.
\end{abstract}

statistical model / farm gate nitrogen surplus / dairy farm / livestock units of dairy cows ha ${ }^{-1}$ / multiple linear regression

\section{INTRODUCTION}

Efficient use of resources, particularly of nutrients, is one of the major assets of sustainable agricultural production systems. Inefficient nutrient use not only results in excessive and potentially harmful losses to the environment, it also negatively affects economic performance of production systems (Oenema and Pietrzak, 2002). The European Union has imposed goals to limit losses of minerals and nutrients to groundand surface waters and has suggested measures to reach these goals. The attention is mainly directed towards the leaching and volatilization of nitrogen. The goal for nitrogen is that surface and groundwater should contain less than $50 \mathrm{mg} \mathrm{ni}-$ trate $\mathrm{L}^{-1}$ (Kuipers and Mandersloot, 1999).

Introducing nutrient balances on farms increases awareness on nutrient flows in the farming system and the information can serve as a guideline for improvements in nutrient management (Ondersteijn, 2002; Goodlass et al., 2003; Hanegraaf and Den Boer, 2003; Swensson, 2003). There has been a lot of research related to nutrient (nitrogen) balances (for a review see Slak et al., 1998; Kuipers and Mandersloot, 1999; Mulier et al.,

* Corresponding author: elenram@yahoo.com
2003; Schröder et al., 2003). Several authors tried to model decision-making and many models have been created (Dou et al., 1996; Ekman, 2002; Freibauer and Kaltschnitt, 2003; Hansen et al., 2000; Kristensen et al., 2000), but either they do not quantify the effect of each independent variable (their models are not statistical models), they are not designed and validated to use under Flemish conditions, or they do not focus on the general $\mathrm{N}$ surplus but on the nitrate leaching, volatilization of ammonia or emission of nitrous oxide.

To our knowledge, there are no multiple regression analyses reported to quantify the effects of managerial aspects on the $\mathrm{N}$ surplus of farms. This research introduces the statistical quantification and comparison of the influence of the different inputs and other variables in the nitrogen surplus at the farm level in Flemish dairy farms. The statistical approach is chosen because it is appropriate when there are uncertainties surrounding the systems under study. Statistical modeling plays an important role in assisting in higher level decisionmaking, process monitoring, data analysis and in statistical process control. Statistical models can yield useful information in a relatively short time frame and in a cost-effective manner where enough data and information have already been generated (Wells and Cole, 2001). 
Table I. Average farm characteristics of specialized dairy farms during 1989-2001 (modified from Nevens et al., 2006).

\begin{tabular}{|c|c|c|c|c|c|c|c|c|}
\hline Year & & 1989 & 1991 & 1993 & 1995 & 1997 & 1999 & 2001 \\
\hline Number of farms & & 169 & 159 & 123 & 115 & 98 & 92 & 69 \\
\hline Utilized area & (ha) & 27.6 & 27.7 & 27.7 & 29.5 & 32.3 & 31.8 & 32.4 \\
\hline $\begin{array}{l}\text { Share of grassland } \\
\text { Annual values }\end{array}$ & $(\%)$ & 70 & 68 & 65 & 63 & 60 & 62 & 63 \\
\hline $\begin{array}{l}\text { Concentrate use } \\
\text { Mineral } \\
\text { fertilization }\end{array}$ & $\begin{array}{l}\left(\mathrm{kg} \mathrm{cow}{ }^{-1}\right) \\
\left(\mathrm{kg} \mathrm{N} \mathrm{ha}^{-1}\right)\end{array}$ & 1236 & 1180 & 1171 & 1291 & 1201 & 1114 & 1132 \\
\hline On grassland & & 309 & 277 & 266 & 246 & 273 & 241 & 186 \\
\hline $\begin{array}{l}\text { On arable land } \\
\text { Milk production }\end{array}$ & (litre) & 98 & 82 & 71 & 62 & 56 & 53 & 40 \\
\hline Per cow & & 5319 & 5458 & 5621 & 5709 & 6182 & 5947 & 5827 \\
\hline Per ha & & 9607 & 9625 & 10060 & 10071 & 10328 & 10014 & 9643 \\
\hline Stocking density ${ }^{a}$ & $\left(\mathrm{LU} \mathrm{ha}{ }^{-1}\right)$ & 3.02 & 3.10 & 3.10 & 3.18 & 3.06 & 2.99 & 2.98 \\
\hline
\end{tabular}

${ }^{a}$ Stocking density is expressed on the total area of the farm, i.e., including arable land. LU: Livestock unit.

The objective of this study was to develop a regression equation including as many independent variables as possible to have the most information content to reduce the $\mathrm{N}$ surplus $\mathrm{ha}^{-1}$ on the farm level. The exclusion of certain variables from the equation may bias the regression coefficients of the variables included in the equation due to specification error or to the presence of spurious relationships.

\section{MATERIALS AND METHODS}

\subsection{Characterizing the dataset}

Data used in this research was stored in the Farm Accountancy Data Network (FADN), which holds technical and economic data of Flemish farms. 233 specialized dairy farms were selected in the FADN. Specialized dairy farms are farms where dairy produces at least $95 \%$ of the farm income. Table I shows some characteristics of specialized Flemish dairy farms and Table II shows the average $\mathrm{N}$ balance of Flemish dairy farms.

The farms were followed during the period 1989-2001. Not all farms were monitored during all years: some farms left the network, others joined the network during the monitoring period. In total, 1298 observations were available. Since several farms were recorded in subsequent years, a random effect for "Farm" was introduced into the models in order to deal with the intra-farm dependence of the observations. The selected farms did not buy forage maize and had no $\mathrm{N}$ input by fixation since they had neither leguminous crops on their arable land nor substantial abundance of white clover (Trifolium repens) in their grassland. They did buy straw and by-products from the food industry. More characteristics of the selected dairy farms are presented in Nevens et al. (2006).

\subsection{Conceptualizing a farm gate balance and calculating the nitrogen surplus}

The farm gate $\mathrm{N}$ surplus was calculated as:

$\mathrm{N}$ surplus $\mathrm{ha}^{-1}=($ Total $\mathrm{N}$ input - Total $\mathrm{N}$ output $) /$ ha
Table II. Flemish dairy farms in 1989 and 2001: components of the N balance ( $\mathrm{kg} \mathrm{N} \mathrm{ha}^{-1}$ year $^{-1}$ ) (standard deviation in brackets) (modified from Nevens et al., 2006).

\begin{tabular}{lcc}
\hline & 1989 & 2001 \\
\hline N input & & \\
Mineral fertilizer & $238(82)$ & $128(57)$ \\
Concentrates & $104(50)$ & $76(36)$ \\
Manure & $25^{a}$ & $29(43)$ \\
Straw & $1(3)$ & $1(3)$ \\
Forages, by-products & $26(35)$ & $17(32)$ \\
Deposition & $50^{a}$ & $48^{a}$ \\
Fixation & $2(9)$ & $6(16)$ \\
Total & $446(121)$ & $305(90)$ \\
& & \\
N output & & \\
Milk & $47(19)$ & $49(21)$ \\
Animals & \\
Crops & $19(8)$ & $16(7)$ \\
Total & $2(5)$ & $2(6)$ \\
N surplus & $68(24)$ & $67(24)$ \\
\hline
\end{tabular}

${ }^{a}$ The same value was used for all the farms.

${ }^{b}$ Net result of sold animals minus purchased animals.

Total $\mathrm{N}$ input is the sum of $\mathrm{N}$ in purchased concentrates, forages and by-products, straw (or sawdust), animals, mineral fertilizer and manure, in biological fixation and in atmospheric deposition. In order to estimate the area of grasslands with clover, we considered grasslands to be grass/clover mixtures when applied mineral $\mathrm{N}$ fertilization was less than $100 \mathrm{~kg}$ $\mathrm{N}$ ha $^{-1}$ year $^{-1}$. However, in some farms a low percentage of clover might have been present, despite a $\mathrm{N}$ fertilization exceeding $100 \mathrm{~kg} \mathrm{~N} \mathrm{ha}^{-1}$ year $^{-1}$. Total $\mathrm{N}$ output is the total amount of $\mathrm{N}$ in exported milk, animals, manure and crops. All inputs and outputs are expressed in $\mathrm{kg} \mathrm{N} \mathrm{ha}^{-1}$ of the total utilized farm area. A detailed description of the calculation of the balance is presented in Nevens et al. (2006). 


\subsection{Statistical analysis}

The development of the statistical analysis of farm data was done in different steps. There were 24 candidate independent variables available to construct the models. First, several multiple linear regression methods (ascendant and descendant substantive knowledge methods, stepwise methods and bestsubsets method) were used in order to find as many candidate models as possible. In total, 83 models were developed, and 51 of them were developed with the descendant substantive knowledge method. The final model was constructed with the descendant substantive knowledge method. The descendant substantive knowledge method is the simplest, yet perhaps the most demanding, approach to specify the regression model, wherein the researcher completely specifies the set of independent variables to be included. The researcher has total control over the variable selection (Hair et al., 1998). This method starts by including in the equation all candidate independent variables and proceeds by eliminating step by step the independent variables that are not relevant enough. The criteria to eliminate variables are the researcher's knowledge based on previous literature and the partial correlation of the independent variables with the dependent variable $\mathrm{N}$ surplus $\mathrm{ha}^{-1}$.

Secondly, the verifications of the assumptions of multiple linear regression were conducted:

1. The relationship between the dependent variable and the independent variables is linear, at least approximately.

2. The error term has zero mean and constant variance.

3. The errors are uncorrelated and normally distributed.

Thirdly, the degree of multicollinearity (correlation among the independent variables, which is not desirable) was checked in order to assure a correct interpretation of the regression coefficients and interaction effects were checked.

The final model was selected as follows. Models fulfilling the assumptions of multiple linear regression were given scores by considering the number of variables included (the more variables, the higher the score), the degree of multicollinearity (the lower it is, the higher the score), the interaction effects (the less there are, the higher the score) and the $\mathrm{R}^{2}$ (the higher it is, the higher the score). Addition of these individual scores resulted in a total score. The model with the best total score was selected as the final model.

Influential observations of the final model were detected by the following methods: standardized residuals, leverage points, Cook's distance, standardized difference in fit, standardized difference in fit of beta and covariance ratio.

The Leave-one-out method of cross-validation was used to validate the final model.

Two different statistical software packages were used: SPSS 16 and S-PLUS 6.1. S-PLUS is the most adequate program to test the functional form of the relationships between the dependent and independent variables. The stepwise methods are most practically performed with this software. This program also allows a fast interaction analysis. SPSS gives the most complete information about the multicollinearity diagnostics (tolerance values, variance inflation factor (VIF), condition index and the proportion of the variance).

\section{RESULTS AND DISCUSSION}

The final model had the following regression equation:

$$
\begin{aligned}
& \mathrm{N} \text { Surplus ha }{ }^{-1}=79.459+1.110 \mathrm{~kg} \text { of } \mathrm{N} \text { in straw } \mathrm{ha}^{-1} \\
& +1.003 \mathrm{~kg} \text { of } \mathrm{N} \text { in fertilizer ha }{ }^{-1} \\
& +0.977 \mathrm{~kg} \text { of N in concentrates ha }{ }^{-1} \\
& +1.003 \mathrm{~kg} \text { of } \mathrm{N} \text { in by-products } \mathrm{ha}^{-1} \\
& -37.536 \mathrm{LU} \text { dairy cows ha }{ }^{-1} \\
& -0.833 \% \text { arable crops }
\end{aligned}
$$

where one LU dairy cows $\mathrm{ha}^{-1}$ represents a dairy cow with a production level of $4000 \mathrm{~L}_{\text {year }}{ }^{-1}$; each extra production of $1000 \mathrm{~L}$ year $^{-1}$ adds $0.1 \mathrm{LU}$.

Table III shows a resume of the main characteristics of the final model.

The final model fulfils the assumptions of multiple linear regression as presented in Table III. The residual plot and histogram adopted adequate patterns.

The relationship between the dependent variable and the independent variables is quasi-linear and the mean of the residuals for the whole range of the dependent variable is very close to zero. The error term has constant variance: moving along the $x$-axis, the values of the residuals do not show an ascendant or descendant pattern. The residuals can be confined in a horizontal band.

\subsection{Interpretation of the regression coefficients}

\subsubsection{Unstandardized coefficients}

The unstandardized regression coefficients show how much a variation of one unit of an independent variable will influence the dependent variable $\mathrm{N}$ surplus $\mathrm{ha}^{-1}$, provided that the rest of the independent variables are kept at a constant level.

As indicated in Table III, a change of $1 \mathrm{~kg}$ of $\mathrm{N}$ in straw ha ${ }^{-1}, 1 \mathrm{~kg}$ of $\mathrm{N}$ in fertilizer ha- $\mathrm{ha}^{-1}, 1 \mathrm{~kg}$ of $\mathrm{N}$ in byproducts $\mathrm{ha}^{-1}$ and $1 \mathrm{~kg}$ of $\mathrm{N}$ in concentrates $\mathrm{ha}^{-1}$ causes a change of approximately 1 unit in $\mathrm{N}$ surplus ha ${ }^{-1}$ in the same direction; the increase of one percent arable crops will cause a decrease of 0.833 units in the $\mathrm{N}$ surplus $\mathrm{ha}^{-1}$ and the increase of one unit of LU dairy cows ha ${ }^{-1}$ will cause a decrease of 37.536 units in the $\mathrm{N}$ surplus $\mathrm{ha}^{-1}$. The negative sign of LU dairy cows ha ${ }^{-1}$ is unexpected. This negative sign is not due to multicollinearity, but due to the inclusion of the relevant variables in the regression equation. The causes, explanation and demonstration of this negative sign are given in the paragraph "Interpretation of the negative sign of the independent variable LU dairy cows ha ${ }^{-1} "$.

The magnitudes of the unstandardized coefficients are different because the influence of every independent variable on the $\mathrm{N}$ surplus ha ${ }^{-1}$ is different and because the range of the independent variables in the database is also different. The fertilizer use ranges from 35 to $543 \mathrm{~kg} \mathrm{~N} \mathrm{ha}^{-1}$ but the LU dairy cows 


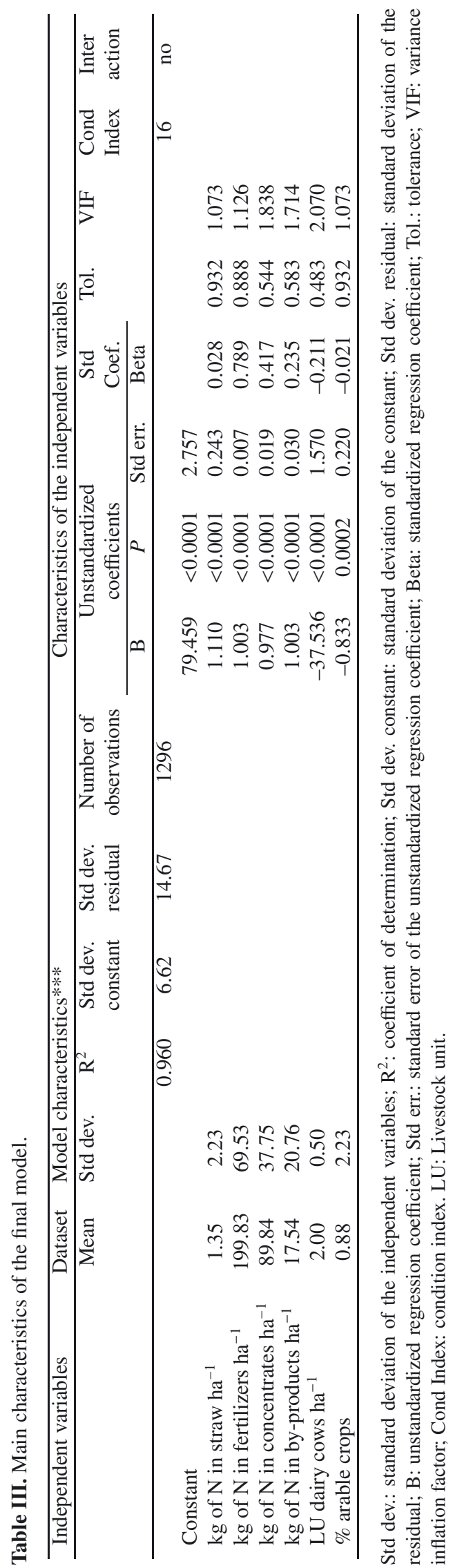

$\mathrm{ha}^{-1}$ ranges from 0.65 to 5.15 . Therefore, the unstandardized coefficients are not appropriate to compare the relative importance of the independent variables.

\subsubsection{Standardized (Beta) coefficients}

The value of a beta coefficient expresses how many standard deviations of the dependent variable will change when varying an independent variable with one standard deviation and, hence, it shows the relative importance of each independent variable in the model.

The beta coefficients show that the most relevant variable is $\mathrm{kg}$ of $\mathrm{N}$ in fertilizers ha ${ }^{-1}$ : it has a beta coefficient of 0.789 (Tab. III): an increase of one standard deviation in $\mathrm{kg}$ of $\mathrm{N}$ in fertilizers ha ${ }^{-1}$ (69.53 units) will cause an increase of 0.789 standard deviations in the $\mathrm{N}$ surplus $\mathrm{ha}^{-1}$. So, this variable has the highest priority if one wants to reduce the $\mathrm{N}$ surplus on a dairy farm. $\mathrm{Kg}$ of $\mathrm{N}$ in concentrates ha ${ }^{-1}$ (beta coefficient 0.417 ) is almost half as relevant as $\mathrm{kg}$ of $\mathrm{N}$ in fertilizers ha ${ }^{-1}$ and the relevance of $\mathrm{kg}$ of $\mathrm{N}$ in by-products ha ${ }^{-1}$ (beta coefficient of 0.235) is about one-third of the relevance of $\mathrm{kg}$ of $\mathrm{N}$ in fertilizers ha ${ }^{-1}$. LU dairy cows ha ${ }^{-1}$ has a beta coefficient of -0.211 (see subchapter Interpretation of the negative sign of the independent variable LU dairy cows $\mathrm{ha}^{-1}$ ).

\subsubsection{Percentage coefficients}

The percentage coefficients (Tab. IV) may be more useful in practice than the beta coefficients because they are intuitively easier to understand since they relate changes in percentages between the independent variables and the dependent variable and not standard deviations as the beta coefficients do. They were calculated by performing a simple regression of the percentages of change in the fertilizers on the percentage of change in the $\mathrm{N}$ surplus $\mathrm{ha}^{-1}$ by using the final model.

So, as an example, a $10 \%$ change in the variable (2), $\mathrm{kg}$ of $\mathrm{N}$ in fertilizers $\mathrm{ha}^{-1}$, will cause an average variation of $6.4 \%$ in the $\mathrm{N}$ surplus ha- ${ }^{-1}$.

\subsubsection{Interpretation of the negative sign of the independent variable $L U$ dairy cows ha ${ }^{-1}$}

As known from the literature, the more intensive the management of a dairy farm, the higher the $\mathrm{N}$ surplus $\mathrm{ha}^{-1}$ might be. The literature usually does not mention clearly if this variable is considered in a simple regression or in a multiple regression. Because an increase in $\mathrm{LU} \mathrm{ha}^{-1}$ is usually considered as an element of the high intensity of the management, it was surprising to find a negative regression coefficient between LU dairy cows ha ${ }^{-1}$ and the $\mathrm{N}$ surplus ha ${ }^{-1}$ in the final regression model. In the next paragraph we explain the veracity of this statistical result.

Potential causes of an unexpected sign are that (1) the dataset is too small; (2) the variance of the independent variables is too small; (3) the degree of multicollinearity is high; 
Table IV. Percentage coefficients of the final model indicating the average percentage change in the dependent variable by changing an independent variable by $1 \%$. LU: Livestock unit.

\begin{tabular}{|c|c|c|c|c|c|}
\hline \multicolumn{6}{|c|}{ Independent variables } \\
\hline $\begin{array}{l}\text { kg of } \mathrm{N} \text { in } \\
\text { straw ha }{ }^{-1} \\
\text { (1) }\end{array}$ & $\begin{array}{c}\mathrm{kg} \text { of } \mathrm{N} \text { in } \\
\text { fertilizers } \mathrm{ha}^{-1} \\
\text { (2) }\end{array}$ & $\begin{array}{c}\mathrm{kg} \text { of } \mathrm{N} \text { in } \\
\text { concentrates } \mathrm{ha}^{-1} \\
\text { (3) }\end{array}$ & $\begin{array}{c}\mathrm{kg} \text { of } \mathrm{N} \text { in } \\
\text { by-products } \mathrm{ha}^{-1} \\
\text { (4) }\end{array}$ & $\begin{array}{l}\text { LU dairy cows ha }{ }^{-1} \\
\text { (5) }\end{array}$ & $\begin{array}{c}\% \text { arable crops } \\
\text { (6) }\end{array}$ \\
\hline 0.005 & 0.640 & 0.284 & 0.052 & -0.255 & -0.003 \\
\hline
\end{tabular}

Table V. Simple regression of $\mathrm{N}$ surplus ha $\mathrm{h}^{-1}$ on LU dairy cows ha $\mathrm{h}^{-1}$. $\mathrm{R}^{2}$ : coefficient of determination; Std err. est.: standard error of the estimate; B: unstandardized regression coefficient; Std err.: standard error of the unstandardized regression coefficient. LU: Livestock unit.

\begin{tabular}{lccccc}
\hline Variables & Variance & $\mathrm{R}^{2}$ & Std err. est. & \multicolumn{2}{c}{ Unstandardized coefficients } \\
\cline { 5 - 6 } & & & 80.47 & $\mathrm{~B}$ & Std err. \\
\hline & & 0.174 & & $161.762^{*}$ & 9.245 \\
Constant & & & $74.175^{*}$ & 4.475 \\
LU dairy cows ha & & & & \\
\hline
\end{tabular}

${ }^{*} P<0.001$.

(4) computational errors have been made and (5) important independent variables have been included in the model. The cause of the unexpected sign is the inclusion of important independent variables in the model (data not shown).

To check if the presence of important independent variables causes the sign reversal, the simple regression of $\mathrm{N}$ surplus $\mathrm{ha}^{-1}$ on LU dairy cows $\mathrm{ha}^{-1}$ is compared with the multiple linear regression of $\mathrm{N}$ surplus $\mathrm{ha}^{-1}$ on important variables such as $\mathrm{kg}$ of $\mathrm{N}$ in fertilizers $\mathrm{ha}^{-1}$ with a correlation of 0.866 with the dependent variable, $\mathrm{kg}$ of $\mathrm{N}$ in concentrates $\mathrm{ha}^{-1}$ with a correlation of 0.598 and $\mathrm{kg}$ of $\mathrm{N}$ in by-products ha ${ }^{-1}$ with a correlation of 0.471 . The standard error of the regression coefficient of the independent variable LU dairy cows ha ${ }^{-1}$ decreases from 4.475 in simple regression (Tab. V) to 1.570 in multiple regression (Tab. III). This is due to the decrease in the standard error of the estimate: 80.47 in simple regression (Tab. V) down to 16.09 (= $\left(\right.$ Std dev. of the intercept ${ }^{2}+$ Std dev. of the residual $\left.{ }^{2}\right)^{1 / 2}$ ) in multiple regression (Tab. III), which improves the estimation of the regression coefficient by decreasing its standard error.

The positive sign of the variable LU dairy cows $\mathrm{ha}^{-1}$ in simple regression and the negative sign in multiple regression are not really wrong. The partial nature of the regression coefficients in the multiple regression causes the sign reversal. The total regression coefficient of LU dairy cows ha ${ }^{-1}$ in simple regression (74.175) measures the total effect of LU dairy cows $\mathrm{ha}^{-1}$, ignoring the information content in $\mathrm{kg}$ of $\mathrm{N}$ in fertilizers $\mathrm{ha}^{-1}, \mathrm{~kg}$ of $\mathrm{N}$ in concentrates $\mathrm{ha}^{-1}$ and $\mathrm{kg}$ of $\mathrm{N}$ in by-products ha ${ }^{-1}$, the important independent variables. When calculating the multiple regression, including these other variables in the model, the regression coefficient of LU dairy cows $\mathrm{ha}^{-1}$ is -37.536 , and the sign reverses (Tab. III). The reason is that -37.536 in the multiple regression model is a "partial" regression coefficient; it measures the effect of LU dairy cows $\mathrm{ha}^{-1}$ given that the other independent variables are present in the model and are kept constant.

The unexpected negative correlation of LU dairy cows ha ${ }^{-1}$ with the dependent variable $\mathrm{N}$ surplus $\mathrm{ha}^{-1}$ means that the higher (until a certain limit) the stocking density, the lower the surplus of nitrogen will be, provided that feed inputs to the farm and cows are kept at a constant level. This is, however, a very theoretical case. In practice, if the number of cows is increased, the feed supply will be increased as well.

If the feed has to be divided over a higher number of cows, one expects a lower milk production and a lower $\mathrm{N}$ output in the milk per cow. Here, we prove that the $\mathrm{N}$ output in the milk of the extra cows is higher than the sum of the decreases in the milk of the cows of the original herd. In other words, the herd becomes more efficient in $\mathrm{N}$ use.

Kebreab et al. (2001) presented an equation for the relationship between the daily input of $\mathrm{N}$ per cow and the $\mathrm{N}$ output in the milk per cow. The research was performed with 50 cows which were fed amounts of $\mathrm{N}$ from 0.300 to $0.600 \mathrm{~kg} \mathrm{cow}^{-1}$ $\mathrm{day}^{-1}$, in different combinations of concentrates and forages.

The equation is:

$\mathrm{g}$ of milk $\mathrm{N} /$ cow day $=0.19 \times \mathrm{g}$ of $\mathrm{N}$ intake/cow day +38.2 .

This is a linear relationship and not a curve. This interval of feed nitrogen (300-600 g) is just a part of the whole curve that ranges from 0 to 1000 . The curve has been linearized for this interval, which is the interval representing the feed level of many dairy herds.

The cow efficiency is:

$$
\text { Dairy cow efficiency }=\frac{\mathrm{g} \text { of milk N/cow day }}{\mathrm{g} \text { of } \mathrm{N} \text { intake/cow day }} \times 100
$$


substituting g of milk $\mathrm{N} \mathrm{cow}^{-1} \mathrm{day}^{-1}$ with formula (1) results in:

Dairy cow efficiency $=$

$$
\frac{0.19 \times \mathrm{g} \text { of } \mathrm{N} \text { intake/cow day }+38.2}{\mathrm{~g} \text { of } \mathrm{N} \text { intake/cow day }} \times 100
$$

Dairy cow efficiency $=\left(0.19+\frac{38.2}{\mathrm{~g} \text { of N intake } / \text { cow day }}\right) \times 100$.

So, the higher the $\mathrm{N}$ intake $\mathrm{cow}^{-1} \mathrm{day}^{-1}$, the lower the efficiency of the dairy cow.

The definition of surplus is:

$$
\text { Surplus }=\text { Input }- \text { Output. }
$$

Two different scenarios are tested:

Scenario 1: the total feed $\mathrm{N}$ input is fixed as input ${ }_{1}$ and fed to $\mathrm{n}_{1}$ cows.

$$
\text { Surplus }_{1}=\text { Input }_{1}-\text { Output }_{1}
$$

Output is: $^{2}$

$$
\text { Output }_{1}=\text { Milk output }_{1}+\text { Meat output }_{1}+\text { Crops output }_{1}
$$

Milk output 1 is:

Milk output $_{1}=$ Total milk $\mathrm{N}$ production $_{1}$

Milk output ${ }_{1}=\mathrm{n}_{1} \times$ milk $\mathrm{N}$ production $/ \mathrm{cow}_{1}$

Milk N production $/ \operatorname{cow}_{1}=\mathrm{N}$ intake $/ \operatorname{cow}_{1} \times 0.19+38.2$

$$
\mathrm{N} \text { intake } / \operatorname{cow}_{1}=\frac{\text { Total feed } \mathrm{N} \text { input }_{1}}{\mathrm{n}_{1}}
$$

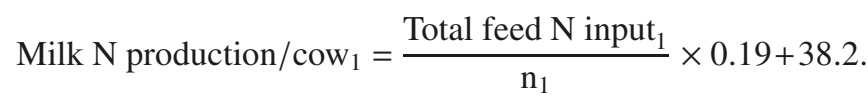

Scenario 2: the total feed $\mathrm{N}$ input stays constant $=$ feed $\mathrm{N}$ input $_{1}$, the number of cows 2 increases to $\mathrm{n}_{2}$. The crops output will also stay constant because it does not depend on the quantity of feed input.

$$
\text { Surplus }_{2}=\text { Input }_{1}-\text { Output }_{2}
$$

Output $_{2}$ is:



Milk Output $_{2}$ is:

Milk output $_{2}=$ Total milk N production 2

Milk output $_{2}=\mathrm{n}_{2} \times$ milk $\mathrm{N}$ production $/ \mathrm{cow}_{2}$

Milk $\mathrm{N}$ production $/ \mathrm{cow}_{2}=\mathrm{N}$ intake $/ \mathrm{cow}_{2} \times 0.19+38.2$

$$
\mathrm{N} \text { intake } / \operatorname{cow}_{2}=\frac{\text { Total feed } \mathrm{N} \text { input }}{\mathrm{n}_{2}}
$$

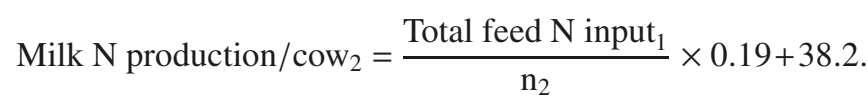

To prove the veracity of the hypothesis we proceed as follows: If: Surplus $_{1}>$ Surplus $_{2}$

$$
\begin{aligned}
\text { Input }_{1}-\text { Output }_{1} & >\text { Input }_{1}-\text { Output }_{2} \\
\text { Output }_{1} & <\text { Output }_{2} .
\end{aligned}
$$

Total milk $\mathrm{N}$ production ${ }_{1}<$ Total milk $\mathrm{N}$ production $_{2}$

$\mathrm{n}_{1} \times$ milk $\mathrm{N}$ production $/ \mathrm{cow}_{1}<\mathrm{n}_{2} \times$ milk $\mathrm{N}$ production $/ \mathrm{cow}_{2}$

$$
\begin{aligned}
& \mathrm{n}_{1} \times\left(\frac{\text { Total feed N input }}{1} \times 0.19+38.2\right)< \\
& \mathrm{n}_{2} \times\left(\frac{\text { Total feed N input }}{1} \times 0.19+38.2\right) \text {. }
\end{aligned}
$$

Total feed $\mathrm{N}$ input $_{1} \times 0.19+38.2 \times \mathrm{n}_{1}<$

$$
\text { Total feed } \mathrm{N} \text { input } 1 \times 0.19+38.2 \times \mathrm{n}_{2}
$$

$$
\mathrm{n}_{1}<\mathrm{n}_{2}
$$

which proves the veracity of the results indeed.

The next step is to calculate how much the number of dairy cows (or livestock units) can increase without jeopardizing the minimum intake limit of $0.300 \mathrm{~kg} \mathrm{~N} \mathrm{cow}^{-1}$ day $^{-1}$.

The potential increase in the number of cows depends on the initial number of cows and on the initial $\mathrm{N}$ intake cow ${ }^{-1}$ day $^{-1}$. The larger the initial herd and the higher the initial intake $\mathrm{cow}^{-1}$ day $^{-1}$, the more extra cows can be included. We have not studied potential effects on animal health and fertility when the $\mathrm{N}$ supply to the dairy cows is very close to the minimum required. Nor have we studied the financial and social implications of a small increase in the dairy cow herd.

\section{CONCLUSIONS}

One final statistical model was developed, which includes most of the relevant variables influencing the nitrogen surplus of Flemish dairy farms as known from the literature.

Comparing the standardized coefficients, the variable $\mathrm{kg}$ of $\mathrm{N}$ in fertilizers ha ${ }^{-1}$ has the highest potential to decrease the $\mathrm{N}$ surplus ha ${ }^{-1}$. The effect of $\mathrm{kg}$ of $\mathrm{N}$ in concentrates ha $\mathrm{ha}^{-1}$ is about 2 times smaller, the effect of $\mathrm{kg}$ of $\mathrm{N}$ in by-products ha ${ }^{-1}$ and LU dairy cows ha ${ }^{-1}$ is about 3 times smaller and the effect of $\mathrm{kg}$ of $\mathrm{N}$ in straw ha $\mathrm{h}^{-1}$ and \% arable crops is about 25 times smaller and hence very small.

It has been demonstrated, at constant feed inputs to the farm, that an increase in LU dairy cows ha ${ }^{-1}$ implies an increase in the total farm output, which causes a decrease in the $\mathrm{N}$ surplus $\mathrm{ha}^{-1}$. The managerial message of these statistical results is that the closer the cows are fed to their minimum requirements, the more efficiently the animals use the $\mathrm{N}$ and the less surplus is created.

The recommendations for Flemish policy-makers, extension services and farmers are (1) to reduce the use of fertilizers and concentrates and (2) to feed the dairy cows as close as possible to their requirements. 
Acknowledgements: The authors gratefully thank the Department of Scientific Politics of the Basque Country Government (Spain) for the 4-year pre-doctoral scholarship, the Flemish Policy Research Center for Sustainable Agriculture contracted from the Flemish Government for financial support and AgriVet of the University of Ghent for its cooperation.

\section{REFERENCES}

Dou Z., Kohn R.A., Ferguson J.D., Boston R.C., Newbold J.D. (1996) Managing nitrogen on dairy farms: An integrated approach I. Model description, J. Dairy Sci. 79, 2071-2080.

Ekman S. (2002) Modelling Agricultural Production Systems using mathematical Programming, $\mathrm{PhD}$ thesis, Swedish University of Agricultural Sciences, Department of Economics, Uppsala.

Freibauer A., Kaltschnitt M. (2003) Controls and models for estimating direct nitrous oxide emissions from temperate and sub-boreal agricultural mineral soils in Europe, Biogeochemistry 63, 93-115.

Goodlass G., Halberg N., Verschuur G. (2003) Input output accounting systems in the European community - an appraisal of their usefulness in raising awareness of environmental problems, Eur. J. Agron. $20,17-24$.

Hair J.F., Anderson R.E., Tatham R.L., Black W.C. (1998) Multivariate data analysis, Prentice-Hall International, Inc.

Hanegraaf M., Den Boer D.J. (2003) Perspectives and limitations of the Dutch minerals accounting system (MINAS), Eur. J. Agron. 20, $25-31$.

Hansen B., Kristensen E.S., Grant R., Hogh-Jensen H., Simmelsgaard S.E., Olesen J.E. (2000) Nitrogen leaching from conventional versus organic farming systems - a systems modelling approach, Eur. J. Agron. 13, 65-82.

Kebreab E., France J., Beever D.E., Castillo A.R. (2001) Nitrogen pollution by dairy cows and its mitigation by dietary manipulation, Nutr. Cycl. Agroecosyst. 60, 275-285.
Kristensen E.S., Hogh-Jensen H., Kristensen I.S. (1995) A simple model for estimation of atmospherically-derived nitrogen in grass-clover systems, Biol. Agric. Hortic. 12, 263-276.

Kuipers A., Mandersloot F. (1999) Reducing nutrient losses on dairy farms in The Netherlands, Livest. Sci. 61, 139-144.

Mulier A., Hofman G., Baecke E., Carlier L., De Brabander D., De Groote G., De Wilde R., Fiems L., Janssens G., Van Cleemput O., Van Herck A., Van Huylenbroeck G., Verbruggen I. (2003) A methodology for the calculation of farm level nitrogen and phosphorus balances in Flemish agriculture, Eur. J. Agron. 20, 45-51.

Nevens F., Verbruggen I., Reheul D., Hofman G. (2006) Farm gate nitrogen surpluses and nitrogen use efficiency of specialized dairy farms is Flanders: Evolution and future goals, Agric. Syst. 88, 142-155.

Oenema O., Pietrzak S. (2002) Nutrient management in food production: achieving agronomic and environmental targets, Ambio 31, $159-168$.

Ondersteijn C.J.M. (2002) Nutrient management strategies on Dutch dairy farms: an empirical analysis. $\mathrm{PhD}$ thesis, Wageningen University, The Netherlands.

Schröder J.J., Aarts H.F.M., Ten Berge H.F.M., Van Keulen H., Neeteson J.J. (2003) An evaluation of whole-farm nitrogen balances and related indices for efficient nitrogen use, Eur. J. Agron. 20, 33-44.

Slak M., Commagnac L., Lucas S. (1998) Feasibility of national nitrogen balances, Environ. Pollut. 102, 235-240.

Swensson C. (2003) Analyses of mineral element balances between 1997 and 1999 from farms in the south of Sweden, Eur. J. Agron. 20, 63-69.

Wells S.A., Cole T.M. (2001) TMDLS: statistical correlations or mechanistic modelling? The National TMDL Science and Policy Conference. 